\title{
Clinicopathologic and prognostic factors in short- and long-term surviving dogs with protein-losing enteropathy
}

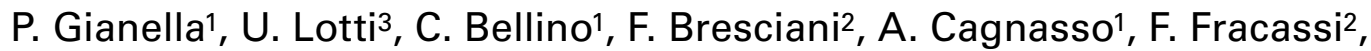 \\ A. D'Angelo', M. Pietra²
}

1 Department of Veterinary Sciences, University of Turin, Italy, ${ }^{2}$ Department of Veterinary Medical Sciences, University of Bologna, Italy, ${ }^{3}$ Veterinary Clinic Valdinievole, Monsummano Terme (PT), Italy

\section{Summary}

The aim of the present study was to investigate the differences in the characteristics of short- and long-term surviving dogs with protein-losing enteropathy (PLE) and to identify factors that predict its outcome. We retrospectively reviewed the medical records of $59 \mathrm{cli}$ ent-owned dogs with PLE diagnosed at three different hospitals between January 2009 and November 2013. The dogs were classified as either short-term ( $\leq 6$ months; STs) or long-term (>6 months; LTs) survivors. Clinical and clinicopathological variables were investigated between the groups and receiver operating characteristic (ROC) curve analysis was performed. Nineteen dogs were classified as STs and 40 as LTs. Body weight and blood urea nitrogen concentrations were significantly higher in the STs at diagnosis $(P<0.05)$. At 1 month after initiation of immunosuppressive therapy (data-driven cut-off, T1), chronic canine enteropathy clinical activity index (CCECAI) scores were higher $(P<0.01)$ and albumin, serum total protein and total cholesterol concentrations were lower $(P<0.01)$ in the STs. ROC curve analysis showed that CCECAI $>5$ evaluated at T1 was the best predictor of poor outcome. Although the severity of clinical signs and the majority of clinicopathological findings at diagnosis did not influence the outcome, survival time was shorter in the dogs with high CCECAI scores at T1 and which did not respond to therapy.

Keywords: canine, inflammatory bowel disease, chronic enteropathy, risk factors, outcome
Klinisch-pathologische und prognostische Faktoren bei kurz- und langfristig überlebenden Hunden mit Eiweissverlustsyndrom

Gegenstand der vorliegenden Untersuchung waren Unterschiede in den Symptomen von kurz- und langfristig überlebenden Hunden mit Eiweissverlustsyndrom (PLE) zu eruieren sowie Faktoren von prognostischer Bedeutung zu identifizieren. Dazu wurden die Krankengeschichten von 59 Hunden mit diagnostiziertem Eiweissverlustsyndrom zwischen Januar 2009 und November 2013 an 3 verschiedenen Kliniken untersucht. Die Hunde wurden jeweils als kurzfristig ( $\leq 6$ Monate; STs) bzw. langfristig ( $\geq 6$ Monate; LTs) überlebend eingestuft. Dabei wurden klinische sowie klinisch-pathologische Schwankungen zwischen den Gruppen abgeklärt sowie eine ROC Kurvenanalyse durchgeführt. Neunzehn Hunde wurden als STs eingestuft, 40 als LTs. Körpergewicht und die Blutharnstoffkonzentration waren bei STs signifikant $(P<0.05)$ höher als bei LTs. Einen Monat nach Beginn einer Immunosuppression (cut-off anhand vorhandener Daten angesetzt, T1) war der klinische Aktivitätsindex von chronischer Enteropathie für Hunde (CCECAI) bei STs höher als LTs $(P<0.01)$, die Werte von Albumin, Gesamteiweiss und Gesamtcholesterin im Blut dagegen tiefer $(P<0.01)$. Bei der ROC Kurvenanalyse erwies sich der bei T1 angesetzte CCECAI $>5$ als zuverlässigster Hinweis auf einen kurz- bzw. langfristigen Verlauf. Obwohl das Ausmass der klinischen Symptome sowie die Mehrzahl der klinisch-pathologischen Befunde die Prognose nicht beeinflussten, war die Überlebensrate der Hunde mit erhöhtem CCECAI bei T1 und bei solchen, welche auf die Therapie nicht angesprochen hatten, geringer.

Schlüsselwörter: Hund, Darmentzündung, chronische Enteropathie, Risikofaktoren, Prognose https://doi.org/ 10.17236/sat00108

Received: 08.04.2016 Accepted: 15.08.2016 
Clinicopathologic and prognostic factors in short- and long-term surviving dogs with protein-losing enteropathy

P. Gianella et al.

\section{Introduction}

Protein-losing enteropathy (PLE) in dogs results from severe small intestinal disease that allows leakage of protein into the intestinal lumen (Dossin and Lavoue, 2011). While panhypoproteinemia associated with loss of albumin and globulin is the most common clinicopathological abnormality, isolated albumin loss can also be observed (Willard et al., 2000; Allenspach et al., 2007). The major causes of PLE in dogs are intestinal lymphangiectasia, inflammatory bowel disease, and lymphoma (Craven et al., 2004; Dandrieux et al., 2013; Nakashima et al., 2015). Because PLE is associated with decreased serum albumin and increased loss of $\alpha_{1}$-PI into the gastrointestinal tract, measurement of serum albumin and fecal $\alpha_{1}$-proteinase inhibitor $\left(\alpha_{1}-\mathrm{PI}\right)$ should be included in the diagnostic workup (Murphy, 2003; Willard, 2013). But since the $\alpha_{1}$-PI test is not readily available, PLE is usually diagnosed after excluding other conditions associated with hypoalbuminemia and intestinal histopathology (Dossin and Lavoue, 2011; Willard, 2013). As compared with chronic enteropathy (CE) with normal albumin (Craven et al., 2004; Allenspach et al., 2007; Simpson and Jergens, 2011), the prognosis for PLE is usually considered guarded (Allenspach et al., 2007; Dossin and Lavoue, 2011), and the response to therapy is variable (Simmerson et al., 2014).

Moreover, information on factors that predict outcome of PLE at diagnosis is limited and long-term follow-up data are lacking. Negative prognostic indicators include medium size (11 to $20 \mathrm{~kg}$ ), high canine IBD activity index (CIBDAI) score, a history of vomiting, monocytosis, mildly increased C-reactive protein, normal serum calprotectin and S100A12 concentrations, clonal rearrangement of lymphocyte antigen receptor genes, and intestinal villous blunting (Simmerson et al., 2014, Equilino et al., 2015; Nakashima et al., 2015). Information on the impact of serum albumin and blood urea nitrogen concentrations on outcome or survival time is controversial. One study found the survival time to be significantly influenced by low blood urea nitrogen concentration and severity of hypoalbuminemia (Simmerson et al., 2014), two others reported that elevated blood urea nitrogen concentration and hypoalbuminemia, but not its severity, were negatively correlated with outcome (Owens et al., 2011; Nakashima et al., 2015), and another found that outcome or survival time were not significantly influenced by the initial serum albumin concentration (Equilino et al., 2015). Finally, while many dogs with PLE secondary to CE die shortly after initiation of treatment, there are some that achieve prolonged survival.

The aim of this study was to retrospectively evaluate the differences in clinical and clinicopathological findings between short- and long-term surviving dogs with PLE secondary to CE at diagnosis and after treatment, and to identify potential risk factors for poor outcome.

\section{Animals, Material and Methods}

\section{History and laboratory findings}

We retrospectively reviewed the medical records of 59 dogs with PLE secondary to CE diagnosed at 3 different hospitals between January 2009 and November 2013. Inclusion criteria were complete history and physical examination findings, chronic gastrointestinal signs lasting for more than 3 weeks, hypoalbuminemia $(<2 \mathrm{~g} / \mathrm{dL})$ of gastrointestinal origin with or without hypoglobulinemia, and histopathological evidence of gastrointestinal inflammation on biopsies collected by endoscopy or laparotomy. Histologic examination was performed in all dogs according to the histopathological standards of the World Small Animal Veterinary Association (WSAVA) Gastrointestinal Standardization Group. All biopsies were retrospectively reviewed by a pathologist blinded to the diagnosis. Chronic canine enteropathy clinical activity index (CCECAI) scores (Allenspach et al., 2007), complete blood count, serum biochemistry and coagulation profiles, pancreas specific lipase levels, serum folate and cobalamin concentrations were gleaned from the medical records. The reference ranges of the hospital laboratories were substantially similar. During review of the medical records (February 2015), follow-up information was obtained by telephone from the owners or referring veterinarians.

\section{Classification and therapy}

Dogs were classified as either short-term (STs) or longterm (LTs) survivors if they had died within or were still alive at 6 months after diagnosis, respectively. Additionally, the medical records were searched for information about the categorization of CE as food-, antibiotic-, or immunosuppressive-responsive. Dogs that showed complete remission of clinical signs while on elimination diet (hydrolysed or restricted antigen diets) were categorized as having food-responsive CE. Dogs that showed complete remission of clinical signs while on tylosin $(15 \mathrm{mg} / \mathrm{kg}, \mathrm{PO}, \mathrm{q} 12 \mathrm{~h})$ or metronidazole $(10 \mathrm{mg} / \mathrm{kg}, \mathrm{PO}$, $\mathrm{q} 12 \mathrm{~h}$ ) were categorized as having antibiotic-responsive CE. Dogs that responded to oral prednisone $(1 \mathrm{mg} / \mathrm{kg}$, twice a day for 2-3 weeks before considering dose reduction), oral azathioprine ( 1 or $2 \mathrm{mg} / \mathrm{kg}$, once a day), oral chlorambucil ( $4-6 \mathrm{mg} / \mathrm{m} 2$, once a day for at least 2 weeks before considering dose reduction), or oral cyclosporine (5 $\mathrm{mg} / \mathrm{kg}$, once a day) were categorized as having immunosuppressive-responsive CE. Dogs were classified as immunosuppressive-unresponsive if they showed poor or no clinical response to immunosuppressives (partial disappearance or persistence of clinical signs). 
Since the medical records also reported the results of repeated exams at follow-up visits, we set T1 (1 month after initiation of immunosuppressives) as the time point at which the clinical and clinicopathological information was complete for the majority of the dogs.

\section{Statistical analysis}

Statistical analysis was performed with a commercially available statistical data analysis program $\left(\right.$ MedCalc $\left.{ }^{\circledR}\right)$. Assessment of data for normality was calculated using the D'Agostino-Pearson test. Continuous variables were expressed as mean $( \pm \mathrm{sd})$, median (minimum and maximum), percentages or both. Categorical variables were expressed as normal/negative (0) or abnormal/positive (1). Fisher's exact test was used to compare between the STs and the LTs the variables: sex, complaints/clinical signs (small bowel diarrhea, mixed diarrhea, decreased appetite, increased appetite, vomiting, peripheral edema, ascites, pleural effusion, pruritus, polyuria and polydipsia, lethargy, and muscular twitching/convulsions), results of the SNAP cPL ${ }^{\circledR}$ test, coagulation profile at $\mathrm{T} 0$, and treatments with different types of immunosuppressives.

Student's t-test was used to compare between the STs and the LTs the variables: age, body weight, CCECAI scores, serum albumin, folate concentrations, and lipase activity at T0 and the CCECAI scores, serum albumin and globulin concentrations at T1. The Mann-Whitney test was used to compare between the STs and the LTs the variables: number of monocytes and platelets, globulin, serum total protein, total cholesterol, blood urea nitrogen, magnesium, cobalamin and fibrinogen concentrations at $\mathrm{T} 0$ and the serum total protein, magnesium and total cholesterol concentration at T1. Values of $P<0.05$ were considered significant. A receiver operating characteristic (ROC) curve was used to select the optimum cut-off value of the variables at T1 to discriminate the STs from the LTs.

\section{Results}

\section{History, physical examination and CCECAI scores}

We reviewed the medical records of 59 dogs with PLE secondary to CE diagnosed between January 1, 2009 and November 30, 2013. Of these 59 dogs, 19 were classified as STs and 40 as LTs. Among the STs were dogs from 9 different breeds and 2 mixed-breed dogs. Fourteen were male and 5 female. The age range was from 9 months to 13.4 years (mean, $5.9 \pm 3.3$ ), and the weight range was from 14 to $40 \mathrm{~kg}$ (mean, $23.6 \pm 7.3$ ). Table 1 reports the presenting complaints/clinical signs. The median duration of clinical signs prior to diagnosis was 2 months (range 1-36). The median survival time was
Table 1: List of presenting complaints/clinical signs at diag nosis (T0) in short-term (ST) and long-term (LT) survivors.

\begin{tabular}{l|c|c} 
Variables & $\begin{array}{c}\mathrm{STs} \\
\mathrm{n} / \mathrm{t}\end{array}$ & $\begin{array}{c}\mathrm{LTs} \\
\mathrm{n} / \mathrm{t}\end{array}$ \\
\hline Small bowel diarrhea & $19 / 19$ & $39 / 40$ \\
\hline Mixed diarrhea & $5 / 19$ & $14 / 40$ \\
\hline Decreased appetite & $13 / 19$ & $22 / 40$ \\
\hline Increased appetite & $1 / 19$ & $3 / 40$ \\
\hline Vomiting & $9 / 19$ & $24 / 40$ \\
\hline Peripheral edema & $1 / 19$ & $5 / 40$ \\
\hline Ascites & $6 / 19$ & $20 / 40$ \\
\hline Pleural effusion & - & $3 / 40$ \\
\hline Pruritus & $1 / 19$ & $4 / 40$ \\
\hline Polyuria and polydipsia & $4 / 19$ & $5 / 40$ \\
\hline Lethargy & $2 / 19$ & $8 / 40$ \\
\hline Muscular twitching/convulsion & $1 / 19$ & $4 / 40$ \\
\hline
\end{tabular}

$\mathrm{n}=$ number of dogs showing the complaint/clinical sign $\mathrm{t}=$ total number of dogs

90 days (range 31 to 180). Among the LTs were dogs from 20 different breeds and 9 mixed-breed dogs. Twenty-two dogs were male and 18 female. The age range was from 1 to 11.6 years (mean, $6.5 \pm 2.5$ ), and the weight range was from 1.9 to $45 \mathrm{~kg}$ (mean $17.4 \pm 12.4$ ). Table 1 reports the presenting complaints/clinical signs. The median duration of clinical signs prior to diagnosis was 2 months (range 1-36). The median survival time was 880 days (range 210 to 1,787 ). No statistically significant differences in sex and age between the two groups were found at T0; body weight was significantly higher in the STs $(P<0.05)$. There was no difference in presenting complaints/clinical signs between the STs and the LTs.

CCECAI scores were available for all dogs at T0, and for all dogs except 1 at T1. No significant differences in the CCECAI scores between the groups were found at T0; at T1 the CCECAI score was significantly higher in the STs (Figure 1).

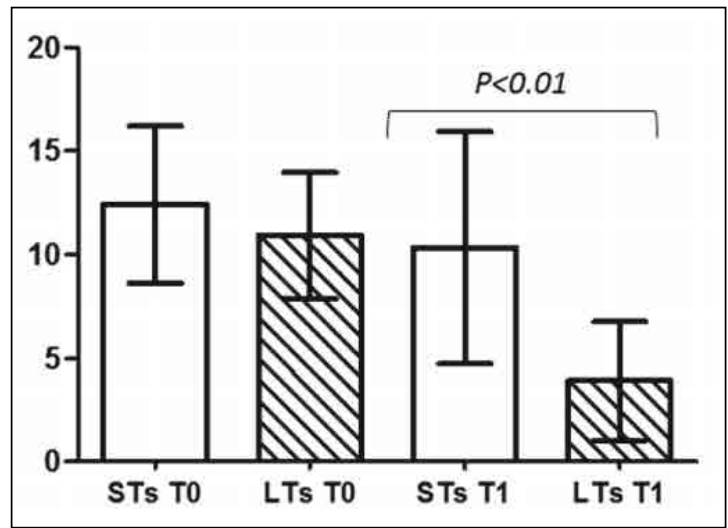

Figure 1: Comparison of canine chronic enteropathy activity scoring index (CCECAI) between short-term (ST) and longterm (LT) survivors at T0 and T1.
Clinicopathologic and prognostic factors in short- and long-term surviving dogs with pro tein-losing enteropathy

P. Gianella et al. 
Clinicopathologic and prognostic factors in short- and long-term surviving dogs with protein-losing enteropathy

P. Gianella et al.

\section{Clinicopathological findings}

Tables 2 and 3 present the clinicopathological findings and the number of dogs that had undergone testing, respectively. At T0, no statistically significant differences between the two groups were found for: number of monocytes and platelets, serum albumin, globulin, total protein, total cholesterol, magnesium, cobalamin, folate and fibrinogen concentrations, lipase activity, results of the SNAP cPL ${ }^{\circledR}$ test, and coagulation profile. Blood urea nitrogen concentrations were significantly higher in the
STs $(P<0.05)$. At T1, albumin, serum total protein and total cholesterol concentrations were significantly lower in the STs $(P<0.01)$.

\section{Gastrointestinal histopathology results}

Gastroduodenoscopy was performed in 58 dogs. Additional ileoscopy and colonoscopy were performed in 14 and 28 dogs, respectively. Laparotomy was performed in $1 \mathrm{dog}$. Tissue quality was classified as adequate in all cases. Moderate to marked histopathologic abnormali-

Table 2: Summary of laboratory results at diagnosis (TO) in short-term (ST) and long-term (LT) survivors.

\begin{tabular}{|c|c|c|c|c|c|}
\hline \multirow[b]{2}{*}{ Variables } & \multicolumn{2}{|c|}{ STs } & \multicolumn{2}{|c|}{ LTs } & \multirow[b]{2}{*}{ Reference values } \\
\hline & $\begin{array}{l}\text { Positive or } \\
\text { abnormal }\end{array}$ & Mean ( \pm SD) & $\begin{array}{l}\text { Positive or } \\
\text { abnormal }\end{array}$ & Mean $( \pm S D)$ & \\
\hline Albumin & - & $1.49( \pm 0.42) \mathrm{g} / \mathrm{dL}$ & - & $1.45( \pm 0.31) \mathrm{g} / \mathrm{dL}$ & $2.80-3.70 \mathrm{~g} / \mathrm{dL}$ \\
\hline Globulin & - & $2.08( \pm 0.87) \mathrm{g} / \mathrm{dL}$ & - & $1.88( \pm 0.61) \mathrm{g} / \mathrm{dL}$ & $2.80-4.20 \mathrm{~g} / \mathrm{dL}$ \\
\hline Total Protein & - & $3.57( \pm 0.97) \mathrm{g} / \mathrm{dL}$ & - & $3.32( \pm 0.75) \mathrm{g} / \mathrm{dL}$ & $5.60-7.90 \mathrm{~g} / \mathrm{dL}$ \\
\hline Total Cholesterol & - & $118( \pm 54) \mathrm{mg} / \mathrm{dL}$ & - & $122( \pm 48) \mathrm{mg} / \mathrm{dL}$ & $140-350 \mathrm{mg} / \mathrm{dL}$ \\
\hline Magnesium & - & $1.67( \pm 0.86) \mathrm{mg} / \mathrm{dL}$ & - & $1.88( \pm 1.90) \mathrm{mg} / \mathrm{dL}$ & $1.60-3.20 \mathrm{mg} / \mathrm{dL}$ \\
\hline Blood Urea Nitrogen & - & $37.62( \pm 18.65) \mathrm{mg} / \mathrm{dL}$ & - & $28.72( \pm 17.32) \mathrm{mg} / \mathrm{dL}$ & $18-55 \mathrm{mg} / \mathrm{dL}$ \\
\hline Cobalamin & - & $219( \pm 128) \mathrm{ng} / \mathrm{L}$ & - & $229( \pm 107) \mathrm{ng} / \mathrm{L}$ & $250-730 \mathrm{ng} / \mathrm{L}$ \\
\hline Folate & - & $9.95( \pm 5.80) \mu \mathrm{g} / \mathrm{L}$ & - & $10.42( \pm 5.90) \mu \mathrm{g} / \mathrm{L}$ & $7-17 \mu \mathrm{g} / \mathrm{L}$ \\
\hline Fibrinogen & - & $450( \pm 146) \mathrm{mg} / \mathrm{dL}$ & - & $555( \pm 225) \mathrm{mg} / \mathrm{dL}$ & $150-450 \mathrm{mg} / \mathrm{dL}$ \\
\hline Lipase & - & $191( \pm 123) \mathrm{U} / \mathrm{L}$ & - & $302( \pm 205) \mathrm{U} / \mathrm{L}$ & $70-700 \mathrm{U} / \mathrm{L}$ \\
\hline SNAP cPL ${ }^{\circledR}$ & 2 & - & 3 & - & - \\
\hline Number of platelets & - & $\begin{array}{c}463,684( \pm 218,761) \\
\text { cells } / \mu \mathrm{L}\end{array}$ & - & $\begin{array}{c}426,056( \pm 252,977) \\
\text { cells } / \mu \mathrm{L}\end{array}$ & $\begin{array}{c}150,000-500,000 \\
\text { cells } / \mu \mathrm{L}\end{array}$ \\
\hline Number of monocytes & - & $\begin{array}{c}686( \pm 482) \\
\text { cells } / \mu \mathrm{L}\end{array}$ & - & $\begin{array}{c}634( \pm 396) \\
\text { cells } / \mu \mathrm{L}\end{array}$ & $\begin{array}{l}100-1400 \\
\text { cells } / \mu \mathrm{L}\end{array}$ \\
\hline Coagulation profile & 9 & - & 10 & - & - \\
\hline
\end{tabular}

Table 3: Summary of clinicopathological variables tested at diagnosis (T0) and 1 month after initiation of immunosuppressive therapy (T1) in short- term (ST) and long-term (LT) survivors.

\begin{tabular}{|c|c|c|c|c|}
\hline \multirow[b]{2}{*}{ Variable } & \multicolumn{2}{|c|}{ T0 } & \multicolumn{2}{|c|}{ T1 } \\
\hline & $\begin{array}{l}\text { STs } \\
n / t\end{array}$ & $\begin{array}{c}\text { LTs } \\
\mathrm{n} / \mathrm{t}\end{array}$ & $\begin{array}{c}\text { STs } \\
n / t\end{array}$ & $\begin{array}{c}\text { LTs } \\
\mathrm{n} / \mathrm{t}\end{array}$ \\
\hline Albumin & $19 / 19$ & $40 / 40$ & $18 / 19$ & $40 / 40$ \\
\hline Globulin & $19 / 19$ & $40 / 40$ & $18 / 19$ & $39 / 40$ \\
\hline Total Protein & $19 / 19$ & $40 / 40$ & $18 / 19$ & $39 / 40$ \\
\hline Total Cholesterol & $19 / 19$ & $38 / 40$ & $13 / 19$ & $31 / 40$ \\
\hline Magnesium & $9 / 19$ & $26 / 40$ & $6 / 19$ & $18 / 40$ \\
\hline Blood Urea Nitrogen & $19 / 19$ & $37 / 40$ & - & - \\
\hline Cobalamin & $13 / 19$ & $30 / 40$ & - & - \\
\hline Folate & $13 / 19$ & $32 / 40$ & - & - \\
\hline Fibrinogen & $5 / 19$ & $16 / 40$ & - & - \\
\hline Lipase & $10 / 19$ & $27 / 40$ & - & - \\
\hline SNAP $\mathrm{cPL}^{\circledR}$ & $5 / 19$ & $17 / 40$ & - & - \\
\hline Number of platelets & $19 / 19$ & $38 / 40$ & - & - \\
\hline Number of monocytes & $18 / 19$ & $32 / 40$ & - & - \\
\hline Coagulation profile & $6 / 19$ & $13 / 40$ & - & - \\
\hline
\end{tabular}

$\mathrm{n}=$ number of dogs in which the variable was measured

$\mathrm{t}=$ total number of dogs 
ties in the small intestine were found in all dogs. Lymphocytic-plasmacytic inflammation (50 dogs) and lymphangiectasia (28 dogs) were the most common abnormalities. Moderate to severe lymphocytic-plasmacytic colonic inflammation was found in 24 dogs.

\section{Treatment and outcome}

No significant differences in the treatments with different types of immunosuppressive therapies were found between the two groups. Based on their response, all STs were categorized as immunosuppressive-unresponsive. Among the LTs, 32 dogs were categorized as immunosuppressive, 1 and 1 each as food- and antibiotic-responsive CE, respectively; 6 dogs were categorized as immunosuppressive-unresponsive.

Follow-up information was available for all dogs. Thirty-three dogs $(55.9 \%$; 31 with immunosuppressive-responsive CE; 1 with food-responsive CE; 1 with antibiotic-responsive $\mathrm{CE}$ ) were alive at the time of medical record review (73 months), and 26 (44.1\%; 19/19 STs and 7/40 LTs with immunosuppressive-responsive CE) had died because of PLE-related complications. The main cause of death was deterioration of clinical conditions presumably due to malabsorption. A cut-off CCECAI score of $>5$ at T1 was found to be the best predictor for poor outcome (Figure 2).

\section{Discussion}

With this retrospective multicenter study we compared the clinical and clinicopathological findings of 59 shortand long-term surviving dogs with PLE secondary to $\mathrm{CE}$, and investigated potential prognostic factors. Consistent with previous observations, the adult dogs of any size were affected by PLE (Allenspach et al., 2007; Lecoindre et al., 2010; Dossin and Lavoue, 2011; Dandrieux et al., 2013; Simmerson et al., 2014), with a predominance of males, however (Kull et al., 2001; Simmerson et al., 2014). Medium size (11 to $20 \mathrm{~kg}$ ) has recently been reported as a negative prognostic indicator (Equilino et al., 2015). When we compared the two groups, we observed that body weight was significantly higher among the STs. This might simply reflect the type of study population or suggest that large breed dogs might be affected by more severe forms of PLE.

Small bowel diarrhea and decreased appetite were the most common historical complaints in both groups. A recent retrospective study found that vomiting was a negative prognostic factor (Simmerson et al., 2014), however, we noted no significant differences in the presenting complaints/clinical signs between the two groups at T0. As seen also in our sample, ascites or pleural effusion are common complaints or physical exam-

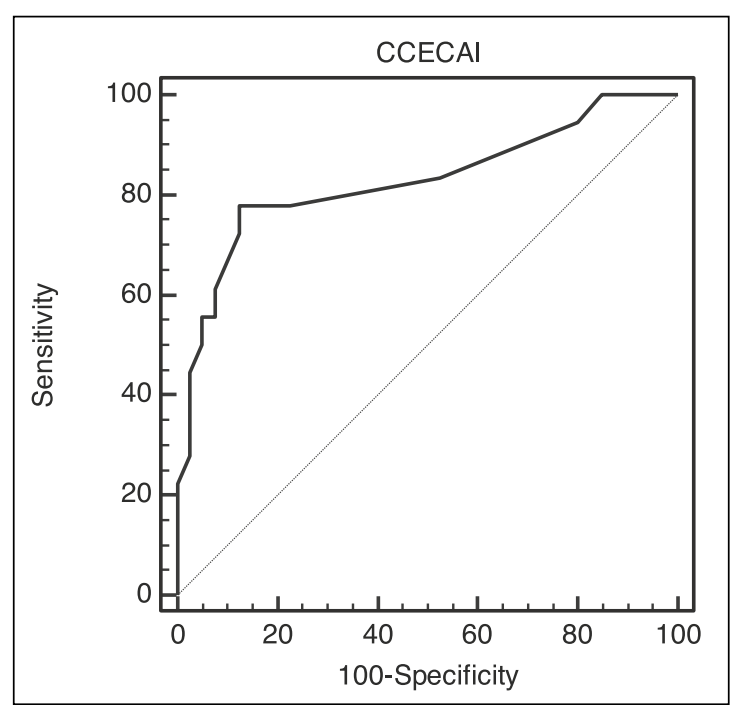

Clinicopathologic and prognostic factors in short- and long-term surviving dogs with protein-losing enteropathy

P. Gianella et al.
Figure 2: The receiver operating characteristic (ROC) curve used to select the optimum cut-off value of the variable CCECAI associated with survival to discriminate between short-term (ST) and long-term (LT) survivors.

ination findings in dogs with PLE (Allenspach et al., 2007, Lecoindre et al., 2010) but they do not seem to be negative prognostic indicators (Simmerson et al., 2014). Activity indices for assessing disease severity can also be used as prognostic markers (Jergens et al., 2003; Allenspach et al., 2007). According to one study, CCECAI $\geq 12$ at diagnosis predicted refractoriness to treatment and euthanasia within 3 years (Allenspach et al., 2007). To the contrary, in our and in a recent study (Equilino et al., 2015), outcome or survival time were not significantly influenced by activity indices at diagnosis.

The only significant difference in pathologic variables between the two groups at $\mathrm{T} 0$ was the blood urea nitrogen concentration, which can be influenced by dehydration, renal failure or severe GI protein loss. But because we had no information about prerenal and renal azotemia values in these PLE dogs, this result should be interpreted with caution. Furthermore, the retrospective design of the present study is an additional limitation. Several variables tested at $\mathrm{T} 0$ were not available at $\mathrm{T} 1$ for all dogs, and treatments were not strictly standardized. That said, collectively, our results may support the hypothesis that the severity of clinical signs and the majority of serum biochemistry and coagulation profile findings at diagnosis do not appear to correlate with outcome.

The prognosis for dogs with PLE in the current veterinary literature is guarded (Allenspach et al., 2007; Dossin and Lavoue, 2011). Except for a recent retrospective study (Simmerson et al., 2014), there are few reports of survival data for dogs with PLE (Craven et al., 2009; Simmerson et al., 2009; Dijkstra et al., 2010; Goodwin 
Clinicopathologic and prognostic factors in short- and long-term surviving dogs with protein-losing enteropathy

P. Gianella et al. et al., 2011; Owens et al., 2011; Equilino et al., 2015). Although 32.2\% of the dogs had died within 6 months of diagnosis, a greater proportion $(55.9 \%)$ was still alive at the time of manuscript preparation, suggesting that not only PLE-affected Yorkshire Terriers, but also other PLE-affected breeds may experience remission of clinical signs and prolonged survival despite severity of clinicopathologic findings at diagnosis, as recently described (Equilino et al., 2015).

To our knowledge, no long-term data on the follow-up of dogs with PLE exist. At T1 (6 months follow-up) the CCECAI scores were higher and the albumin, total protein, and total cholesterol concentrations all lower in the STs. Moreover, the dogs with a CCECAI score $>5$ were more likely to die within 6 months of initial diagnosis. Since these variables at T0 did not significantly influence the outcome, they might simply reflect a poor response to therapy. Finally, since all STs were categorized as immunosuppressive-unresponsive, it is reasonable to assume that a poor response to therapy is a poor prognostic indicator. Indeed, survival time was shorter in the dogs with high CCECAI scores at T1 and that were unresponsive to therapy.

In conclusion, the clinical outcomes of PLE are variable, with the majority of the dogs having prolonged survival despite the severity of clinicopathological findings at diagnosis.

\section{Facteurs clinico-pathologiques et pronostics chez les chiens survivant à court et à long terme à un syndrome d'entéropathie exsudative}

Le présent travail avait pour buts d'étudier quels sont les différences de symptômes chez les chiens survivant à court et à long terme à une d'entéropathie exsudative (PLE) et d'identifier les facteurs ayant une valeur pronostique. On a étudié pour cela les dossiers médicaux de 59 chiens sur lesquels une entéropathie exsudative avait été diagnostiquée dans trois cliniques différentes entre janvier 2009 et novembre 2013. Les chiens ont été classés comme survivants à court terme ( $\leq 6$ mois; STs) respectivement à long terme ( $\geq 6$ mois; LTs). Les variations cliniques et clinico-pathologiques entre les groupes ont été relevées et une courbe ROC a été établie. Dixneuf chiens ont été classés comme STs et 40 comme LTs. Le poids corporel et la concentration sanguine d'urée était significativement plus élevée $(P<0.05)$ chez les STs que chez les LTs. Un mois après le début d'une immunosuppression (cut-off établi sur la base des données disponibles, T1), le score clinique d'activité pour une entéropathie chronique chez le chien (CCEAI) était plus élevé chez les STs que chez les LTs $(P<0.01)$, les valeur sanguines d'albumine, de protéines totales et de cholestérine totale par contre plus basses $(P<0.01)$. Dans l'analyse par la courbe ROC, un CCEAI $>5$ à T1 s'est avéré être un indice fiable quant à une évolution de courte ou de longue durée. Bien que l'étendue des symptômes cliniques et la quantité des découvertes clinico-pathologiques n'aient pas influencé le pronostic, le taux de survie des chiens avec un CCEAI élevé à T1 et de ceux qui n'avaient pas répondu au traitement a été plus faible.

\section{Fattori clinico-patologici e prognostici in cani affetti da enteropatia proteino- disperdente con sopravvivenza a breve e lungo termine}

L'obiettivo del presente lavoro è stato di valutare le differenze nelle caratteristiche di cani con sopravvivenza a breve e lungo termine affetti da enteropatia proteinodisperdente (PLE) e di identificarne i fattori prognostici. Abbiamo revisionato retrospettivamente le cartelle cliniche di 59 cani di proprietà con PLE diagnosticata in tre diversi ospedali tra gennaio 2009 e novembre 2013. I cani sono stati classificati come sopravvissuti a breve ( $\leq 6$ mesi; STs), o a lungo termine (>6 mesi; LTs). Le variabili cliniche e clinicopatologiche nei due gruppi sono state confrontate ed é stata eseguita un'analisi della curva ROC. Diciannove cani sono stati classificati come STs e 40 come LTs. Il peso corporeo e le concentrazioni di azoto ureico erano significativamente aumentati negli STs alla diagnosi $(P<0.05)$. Un mese dopo l'inizio della terapia immunosoppressiva (cut-off scelto sulla base dei dati disponibili, T1), i punteggi relativi all'indice di attività clinica dell'enteropatia cronica canina (CCECAI) erano più elevati $(P<0.01)$, le concentrazioni di albumina, proteine sieriche totali e colesterolo totale più basse $(P<0.01)$ negli STs. L'analisi della curva ROC ha mostrato che un CCECAI $>5$ a T1 è stato il miglior valore predittivo di una prognosi sfavorevole. Sebbene la gravità dei sintomi clinici e la maggior parte dei riscontri clinicopatologici alla diagnosi non hanno influenzato la prognosi, la sopravvivenza è stata ridotta nei cani con elevati punteggi CCECAI a T1 e che non hanno risposto alla terapia. 


\section{References}

Allenspach K., Wieland B., Gröne A., Gaschen F.: Chronic enteropathies in dogs: evaluation of risk factors for negative outcome. J. Vet. Intern. Med. 2007, 21: 700-708.

Craven M., Duhamel G. E., Sutter N. B., Simpson K.W.: Absence of bacterial association in Yorkshire terriers with protein-losing enteropathy and cystic intestinal crypts. J. Vet. Intern. Med. 2009, 23: 757.

Craven M., Simpson J. W., Ridyard A. E., Chandler M. L.: Canine inflammatory bowel disease: retrospective analysis of diagnosis and outcome in 80 cases (1995-2002). J. Small Anim. Pract. 2004, 45: 336-342.

Dandrieux J. R. S., Noble P. J. M., Scase T. J., Cripps P. J., German A. J.: Comparison of a chlorambucil-prednisolone combination with an azathioprine-prednisolone combination for treatment of chronic enteropathy with concurrent protein-losing enteropathy in dogs: 27 cases (2007-2010). J. Am. Vet. Med. Assoc. 2013, 242: 1705-1714.

Day M. J., Bilzer T., Mansell J., Wilcock B., Hall E. J., Jergens A., Minami T., Willard M., Washabau R.: Histopathological standards for the diagnosis of gastrointestinal inflammation in endoscopic biopsy samples from the dog and cat: A report from the World Small Animal Veterinary Association Gastrointestinal Standardization Group. J. Comp. Pathol. 2008, 138: S1-S43.

Dijkstra M., Kraus J. S., Bosje J. T., den Hertog E.: Protein-losing enteropathy in Rottweilers. Tijdschr. Diergeneeskd. 2010, 135: 406-412.

Dossin O., Lavoue R.: Protein-losing enteropathies in dogs. Vet. Clin. North. Am. Small Anim. Pract. 2011, 4: 399-418.

Equilino M., Théodoloz V., Gorgas D., Doherr M. G., Heilmann M. R., Suchodolsky J. S., Steiner J. M., Burgener I. A.: Evaluation of serum biochemical marker concentrations and survival time in dogs with protein-losing enteropathy. J. Am. Vet. Med. Assoc. 2015, 246: 91-99.

Goodwin L. V., Goggs R., Chan D. L., Allenspach K.: Hypercoagulability in dogs with protein losing enteropathy. J. Vet. Intern. Med. 2011, 25: 273-277.

Jergens A. E., Schreiner C. A., Frank D. E., Niyo Y., Ahrens F. E:, Eckersall P. D., Benson T. J., Evans R.: A scoring index for disease activity in canine inflammatory bowel disease. J. Vet. Intern. Med. 2003, 17: 291-297.

Kull P. A., Hess R. S., Craig L. E., Saunders H. M., Washabau $R$. J.: Clinical, clinicopathologic, radiographic, and ultrasonographic characteristics of intestinal lymphangiectasia in dogs: 17 cases (1996-1998). J. Am. Vet. Med. Assoc. 2001, 219: 197-202.

Lecoindre P., Chevallier M., Guerret S.: Protein losing enteropathy of non-neoplastic origin in the dog: A retrospective study of 34 cases. Schweiz. Arch. Tierheilk. 2010, 152: 141-146.

Murphy K. F., German A. J., Ruaux C. G., Steiner J. M., Williams D. A., Hall E. J.: Fecal alpha-1 proteinase inhibitor concentration in dogs with chronic gastrointestinal disease. Vet. Clin. Pathol.. 2003, 32: 67-72.

Nakashima K., Hiyoshi S., Ohno K., Uchida K., Goto-Koshino Y., Maeda S., Mizutani N., Takeuchi A., Tsujimoto H.: Prognostic factors in dogs with protein-losing enteropathy. Vet. J. 2015, 205: 28-32.

Owens S. L., Parnell N. K., Moore G. E.: Canine proteinlosing enteropathy: a retrospective analysis and survival study in 68 dogs. J. Vet. Intern. Med. 2011, 25: 692.
Simmerson S. M., Armstrong P. J., Wünschmann A., Jessen C. R., Crews L. J., Washabau R. J.: Clinical features, intestinal histopathology, and outcome in protein-losing enteropathy in Yorkshire Terriers dogs. J. Vet. Intern. Med. 2014, 28: 331-337.

Simmerson S. M., Wünschmann A., Crews L., Amstrong P. J., Fee M., Washabau R.: Description of protein-losing enteropathy in Yorkshire terrier dogs using the W.S.A.V.A. gastrointestinal classification system. J. Vet. Intern. Med. 2009, 23: 732.

Simpson K. W., Jergens A. E.: Pitfalls and progress in the management of canine inflammatory bowel disease. Vet. Clin. North Am. Small Anim. Pract. 2011, 41: 381-398.

Willard M. D.: Diagnosis of Protein-losing enteropathy. In: Canine and Feline Gastroenterology. Eds. Washabau R.J, and Day M.J. St Louis, MO Saunders, 2013, 681-682.

Willard M. D., Helman G., Fradkin J. M., Becker T., Brown R. M., Lewis B. C., Weeks B.R.: Intestinal crypt lesions associated with protein losing enteropathy in the dog. J. Vet. Intern. Med. 2000, 14: 298-307.

\section{Corresponding Author}

P. Gianella

DVM, PhD, Dipl. ACVIM, Assistant Professor

Department of Veterinary Sciences

Clinical Section

University of Turin

Largo P. Braccini 2 (ex Via Leonardo da Vinci 44)

10095 Grugliasco (To) - Italy

Tel. ++39 011-6709074

Fax ++39 011-6709083

E-Mail: paola.gianella@unito.it
Clinicopathologic and prognostic factors in short- and long-term surviving dogs with protein-losing enteropathy

P. Gianella et al. 